\title{
Pemberian Makan Bayi dan Anak (PMBA) pada Masa Pandemi Covid-19
}

\author{
Ratih Kurniasari
}

ratih.kurniasari@fkes.unsika.ac.id

\section{Staff Pengajar S1 Gizi Universitas Singaperbangsa Karawang}

\section{A. DASAR PEMIKIRAN}

Pada awal 2020, Indonesia dikejutkan dengan mewabahnya pneumonia baru yang bermula dari Wuhan, Provinsi Hubei yang kemudian menyebar dengan cepat ke lebih dari 190 negara dan teritori. Wabah ini diberi nama coronavirus disease 2019 (COVID-19) yang disebabkan oleh Severe Acute Respiratory Syndrome Coronavirus-2 (SARS-CoV-2). Penyebaran penyakit ini telah memberikan dampak luas secara sosial dan ekonomi. Saat ini, penyebaran SARS-CoV-2 dari manusiake manusia menjadi sumber transmisi utama sehingga penyebaran menjadi lebih agresif. Transmisi SARS-CoV-2 dari pasien simptomatik terjadi melalui droplet yang keluar saat berbicara, batuk atau bersin.

Pada masa pandemic covid-19 banyak orang tua khawatir menyiapkan MP-ASI yang tepat untuk bayi terutama untuk memilih bahan makanan yang meningkatkan imunitas bayi dan anak ketika diberlakukannya pembatasan sosial berskala besar (PSBB). Makanan Pendamping Air Susu Ibu (MP-ASI) adalah makanan atau minuman yang mengandung zat gizi yang diberikan pada bayi atau anak usia 6-24 bulan guna memenuhi kebutuhan gizi selain ASI (Departemen Kesehatan RI, 2006). Menurut ASDI, MP-ASI merupakan makanan atau minuman selain ASI yang mengandung zat gizi yang diberikan kepada bayi selama periode penyapihan (complementary feeding) $\begin{array}{crr}\text { yaitu pada } & \text { saat } \\ \text { makanan/minuman lain } & \text { diberikan } \\ \text { bersama pemberian ASI. } & \\ \text { Proses optimalisasi } & \text { tumbuh }\end{array}$ kembang dan pertumbuhan otak terjadi pada dua tahun awal kehidupan (Window of Opportunity). Adapun awal kehidupan yang rentan dengan berbagai masalah gizi, terjadi pada dua tahun awal kehidupan, perlu memperhatikan makanan lanjutan setelah ASI yaitu MP-ASI (Laurensi, 2017). MP-ASI yang tepat dan baik merupakan makanan yang dapat memenuhi kebutuhan gizi sehingga bayi dan anak dapat tumbuh kembang dengan optimal (Black C et al, 2013). Salah satu penyebab terjadinya gangguan tumbuh kembang bayi dan anak usia 6-24 bulan di Indonesia adalah rendahnya mutu MP-ASI dan ketidaksesuaian waktu serta gizi yang diberikan sehingga beberapa zat gizi tidak dapat memenuhi kebutuhan energi.

WHO mengeluarkan rekomendasi mengenai pemberian MP ASI yang meliputi 4 syarat, yaitu: pertama tepat waktu (timely), artinya MP ASI harus diberikan saat ASI eksklusif sudah tidak dapat memenuhi kebutuhan zat gizi bayi. Syarat kedua adala adekuat, artinya MP ASI memiliki kandungan energi, protein, dan mikronutrien yang dapat memenuhi kebutuhan makronutrien dan mikronutrien bayi sesuai usianya. Makanan utama harus mengandung karbohidrat, protein hewani, protein nabati, lemak dan vitamin serta 
mineral. Perlu dipastikan juga bahwa MP ASI harus mengandung zat besi yang memang sangat diperlukan oleh bayi. Karena kandungan zat besi dalam ASI pada saat usia 6 bulan sudah sangat sedikit kandungannya sehingga otomatis tidak bisa memenuhi kebutuhan bayi. Makanan berserat berupa sayur dan buah hanya perlu diberikan sedikit saja karena porsi yang besar bisa menghambat penyerapan zat besi.

Syarat ketiga adalah aman, artinya MP ASI disiapkan dan disimpan dengan cara cara yang higienis, diberikan menggunakan tangan dan peralatan makan yang bersih, memisahkan makanan yang mentah dengan yang matang, menggunakan sumber air yang bersih serta cara memasak yang benar dan penyimpanan makanan pada suhu yang tepat. Syarat terakhir adalah diberikan dengan responsive feeding artinya MP ASI diberikan dengan memperhatikan sinyal rasa lapar dan kenyang seorang anak. Frekuensi makan dan metode pemberian makan harus dapat mendorong anak untuk mengonsumsi makanan secara aktif dalam jumlah yang cukup menggunakan tangan, sendok, atau makan sendiri (disesuaikan dengan usia dan tahap perkembangan seorang anak).

Menurut Heryanto (2017) bahwa hambatan utama tercapainya ASI Eksklusif dan pemanfaatan ASI yang benar adalah karena kurangnya pengetahuan yang benar tentang MPASI. Pemberian MP-ASI dengan tepat dan benar akan mendukung tumbuh kembang bayi baik kognitif, psikomotorik dan menumbuhkan kebiasaan makan yang baik. Pemberian MP-ASI dini mempengaruhi tingkat kecerdasan anak setelah usia dewasa dan memicu terjadinya penyakit obesitas, hipertensi dan penyakit jantung koroner.

\section{B. TUJUAN}

Tujuan pengabdian masyarakt ini adalah meningkatkan pengetahuan masyarakat terutama orang tua yang memiliki balita untuk mempersiapakan MP-ASI yang tepat pada masa pandemic covid-19

\section{SASARAN}

Seminar ini ditujukan terutama untuk orang tua yang memiliki balita, pengurus daycare, mahasiswa dan masyarakat pada umumnya.

D. WAKTU DAN TEMPAT

Acara diselenggarakan tanggal 16 April 2020 pukul 13.00-15.00 dengan susunaan acara sebagai berikut :

\begin{tabular}{|c|l|}
\hline WAKTU & \multicolumn{1}{c|}{ KEGIATAN } \\
\hline 12.50-13.00 WIB & \multicolumn{1}{|c|}{$\begin{array}{c}\text { Memastikan moderator dan } \\
\text { narasumber hadir di room }\end{array}$} \\
\hline 13.00-13.10 WIB & $\begin{array}{l}\text {-Pembukaan seminar oleh host } \\
\text {-Laporan ketua pelaksana webinar } \\
2020\end{array}$ \\
\hline 13.10-14.10 WIB & Penyampaian materi \\
\hline 14.10-14.30 WIB & Sesi tanya jawab I (3 pertanyaan) \\
\hline 14.30-14.50 WIB & Sesi tanya jawab II (3 pertanyaan) \\
\hline
\end{tabular}




\begin{tabular}{|l|l|}
\hline 14.50-15.00 WIB & $\begin{array}{l}\text { Penyampaian kesimpulan, penutupan } \\
\text { penyampaian materi, dan penutupan } \\
\text { acara }\end{array}$ \\
\hline
\end{tabular}

\section{E. HASIL KEGIATAN}

Kegiatan dibagi 2 sesi yaitu :

1. Pembahasan pengertian MP-ASI secara umum

Pada pemberian MP-ASI harus memperhatikan $3 \mathrm{M}$ yaitu

\section{a. Minimum Dietary Diversity (MDD \\ WHO/UNICEF dan rekomendasi Kemenkes untuk Pemberian Makanan Bayi dan Anak (PMBA) dalam ketentuannya mengharuskan bayi usia 6-23 bulan dapat MPASI yang adekuat dengan ketentuan dapat menerima minimal 4 atau lebih dari 7 jenis makanan Minimum Dietary Diversity/MDD. Adapun jenis makanan tersebut adalah Serealia/umbi-umbian, kacang- kacangan, produk olahan susu, telur, sumber protein lainnya, sayur dan buah kaya vitamin A, sayur dan buah lainnya.}

\section{b. Minimum Meal Frequency (MMF)}

Orang tua harus memperhatikan tekstur dan porsi MP-ASI yang diberikan.

Anak Usia 6-8 Bulan

1) 6 bulan - bubur saring - transisi dari minum ASI

2) 7-8 bulan - Bubur dengan tekstur semi kental $\rightarrow$ Makanan lumat dan kental seperti bubur atau puree

3) Mulai dengan 2-3 sendok penuh/porsi, kemudian tambahkan kembali secara perlahan hingga setengah dari mangkok berukuran $250 \mathrm{ml}$ (sekitar $125 \mathrm{ml}$ )

4) Mulai dari kategori karbohidrat , buah dan sayur, kacang- kacangan dan sumber protein hewani dan nabati

Anak Usia 9 - 12 Bulan

1) Makanan lembek (nasi tim, bubur tanpa disaring, cincang halus bertahap menjadi cincang kasar)

2) Makanan yang di potong kecilkecil atau di iris.

3) Makanan yang dapat dipegang oleh bayi (Finger Foods)

4) Kurang lebih sebanyak $125 \mathrm{ml}$ bertahap hingga $200 \mathrm{ml}$ atau Setengah dari mangkok berukuran $250 \mathrm{ml}$.

Anak Usia 12 - 23 Bulan

1) Makanan yang dimakan oleh keluarga, boleh dihaluskan jika perlu (disesuaikan dengan kemampuan anak)

2) $3 / 4$ mangkok berukuran $250 \mathrm{ml}$ sekitar $200 \mathrm{ml}$ dilanjutkan bertahap hingga $250 \mathrm{ml}$

\section{c. Minimum Acceptable Diet (MAD)}

Jika MMF dan MDD sudah diberikan dengan tepat bayi yang perlu diperhatikan adalah daya terima makanan yang telah diberikan lalu dievaluasi. Selain itu peru diperhatikan jadwal pemberian MP-ASI, yang kurang lebih dapat dilihat pada tebel di bawah ini :

Tabel Jadwal Pemberian MP-ASI

\begin{tabular}{|l|l|}
\hline Waktu & \multicolumn{1}{|c|}{ Keterangan } \\
\hline 08.00 & Sarapan \\
& ASI/Makanan \\
& Keluarga) \\
\hline
\end{tabular}




\begin{tabular}{|l|l|}
\hline 10.00 & $\begin{array}{l}\text { Snack (buah, biscuit, } \\
\text { pudding, dll) }\end{array}$ \\
\hline 12.00 & $\begin{array}{l}\text { Makan Siang (MP- } \\
\text { ASI/Makanan } \\
\text { Keluarga) }\end{array}$ \\
\hline 16.00 & $\begin{array}{l}\text { Snack (buah, biscuit, } \\
\text { pudding, dll) }\end{array}$ \\
\hline 18.30 & $\begin{array}{l}\text { Makan malam (MP- } \\
\text { ASI/Makanan } \\
\text { Keluarga) }\end{array}$ \\
\hline $19-00 \mathrm{~s} / \mathrm{d}$ & ASI sesuka anak \\
07.00 & \\
\hline
\end{tabular}

d. Pembahasan pemberian Mp-ASI ketikan pandemic covid-19

Orang tua harus memahami jika MP-ASI dapat mengikuti menu yang dipakai oleh anggota keluarga lain, maka semuanya akan jauh lebih praktis. MPASI homemade atau rumahan pada prinsipnya selama orang tua dan anggota keluarga lain dapat memakannya, maka bayi juga bisa, jadi tidak perlu membeda-bedakan yang perlu diperhatikan adalah tekstur dan bahan tambahan makanannya.

WHO merekomendasikan berikan anak makanan segar bukan makanan olahan. Untuk protein, sajikan 2-3 porsi per hari (3 porsi untuk balita vegetarian). Ikan harus disajikan setidaknya dua kali seminggu dan salah satunya adalah ikan berminyak (mis. sarden, mackerel atau salmon). Kacang dianggap protein, dan direkomendasikan untuk anak di atas 2 tahun. Untuk susu, sajikan 3 porsi per hari. Anak-anak di bawah 2 tahun harus mengonsumsi susu atau yogurt. Mereka yang makan dengan baik bisa diberi susu semi-skim setelah 2 tahun. Susu skim tidak cocok sebagai minuman untuk anak di bawah 5 th. Produk yang diperkaya dengan vitamin $\mathrm{D}$ dapat memberikan kontribusi yang berguna untuk dikonsumsi.

Pastikan anak Anda mengkonsumsi 8-10 gelas air setiap hari. Air sangat penting bagi kehidupan. Air mengangkut zat gizi dan senyawa dalam darah, mengatur suhu tubuh, menghilangkan limbah, dan melumasi dan bantal sendi. Air putih adalah pilihan terbaik, tetapi anda juga dapat memberi anak minuman lain (mis. Susu tanpa pemanis), buah dan sayuran yang mengandung air (mis. Mentimun, tomat, bayam, jamur, melon, brokoli, jeruk, apel), dan hindari memberi mereka jus buah manis, sirup, konsentrat jus buah, bersoda, dan masih minum karena semuanya mengandung gula.

Pastikan anak mengkonsumsi lemak sehat. Pastikan anak mengkonsumsi lemak tak jenuh (mis: minyak dalam ikan, alpukat, kacangkacangan, minyak zaitun, kedelai, kanola, minyak bunga matahari dan jagung) daripada lemak je.nuh yang banyak terdapat dalam gajih, minyak jelantah. Berikan anak Anda daging putih (missal ayam) dan ikan, yang umumnya rendah lemak, daripada daging merah. Jangan beri anak Anda daging olahan seperti sosis karena mengandung banyak lemak dan garam. Jangan berikan mereka lemak trans yang diproduksi secara industri (ditemukan dalam makanan olahan, makanan cepat saji, makanan ringan, makanan yang digoreng, pizza beku, sosis).

Batasi asupan garam dan gula anak Anda. Saat memasak dan menyiapkan makanan untuk anak Anda, batasi jumlah garam dan bumbu natrium tinggi (mis. Kecap asin dan kecap ikan). Batasi jumlah garam yang Anda gunakan setiap hari hingga kurang dari $5 \mathrm{~g}$ (sekitar 1 sendok teh), dan gunakan garam beryodium. Jangan memberi anak makanan camilan yang tinggi garam dan gula. Jangan beri mereka minuman ringan atau soda dan minuman lain yang tinggi gula (mis. Jus buah, konsentrat dan sirup jus buah, susu beraroma dan minuman yogurt). 
Ingat: buah segar adalah pilihan terbaik untuk anak Anda, bukan camilan manis seperti kue, kue, dan cokelat. Untuk jus buah dan buah kering, anak-anak di bawah usia 6 tahun tidak boleh lebih dari setengah cangkir jus per hari dan pastikan itu jus buah $100 \%$, bukan minuman jus dengan tambahan gula. Setelah usia 7 th, pertahankan konsumsi jus di bawah $355 \mathrm{ml}$ per hari. Setengah cangkir buah kering setara dengan secangkir penuh buah biasa. Buah segar adalah pilihan terbaik. Untuk camilan, beri anak Anda sayuran mentah dan buah segar daripada makanan yang tinggi gula, lemak, atau garam.

Pastikan Anda tidak terlalu banyak memasak sayur dan buah karena hal ini dapat menyebabkan hilangnya vitamin penting. Jika Anda menggunakan sayuran dan buah kaleng atau kering, pilih varietas tanpa garam atau gula tambahan.

Untuk buah, :

a. Balita yang berusia $2-3$ tahun membutuhkan sekitar 1 porsi buah per hari.

b. Anak-anak usia 4-13 tahun membutuhkan 1,5 porsi buah per hari.

c. Anak perempuan berusia antara 1418 tahun membutuhkan 1,5 porsi buah per hari, dan anak laki-laki seusia itu membutuhkan 2 porsi buah.

Untuk sayuran,

a. Balita berusia antara 2-3 tahun membutuhkan sekitar 1 porsi sayuran mentah atau matang setara dengan 1 gelas per hari.

b. Anak-anak usia 4-8 tahun membutuhkan 1,5 porsi sayuran per hari.

c. Anak perempuan berusia antara 9 13 tahun membutuhkan 2 porsi sayuran per hari, dan anak laki-laki membutuhkan 2,5 porsi. d. Anak perempuan berusia antara 14 - 18 tahun membutuhkan 2,5 porsi sayuran per hari, dan anak laki-laki membutuhkan 3 porsi.

e. Variasikan konsumsi sayuran termasuk sayuran berdaun hijau, sayuran dan kacang-kacangan berwarna merah dan oranye.

\section{F. DOKUMENTASI}

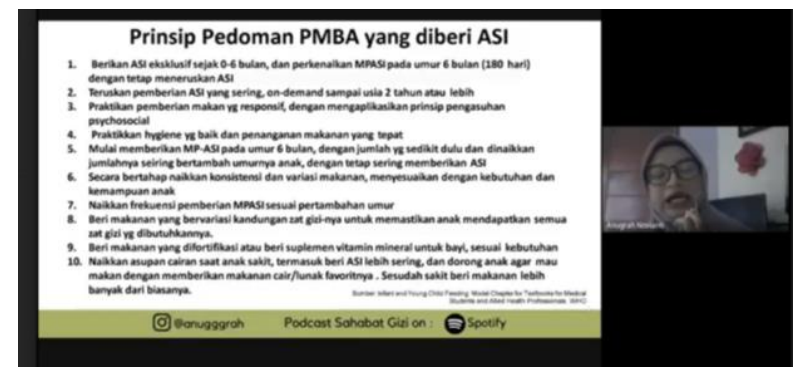

